\title{
NOVÁ DÍLČÍ ZJIŠTĚNÍ K DĚJINÁM FRANTIŠKÁNSKÉ KNIHOVNY U PANNY MARIE SNĚŽNÉ V PRAZE
}

\author{
Jan Kašpar (Praha)
}

\begin{abstract}
New Partial Findings on the History of the Franciscan Library at Our Lady of the Snows in Prague
Abstract: The article summarises new findings and complements earlier studies concerning the history of the library of the Franciscan monastery of Our Lady of the Snows in the New Town of Prague. Its first part deals with the maker of rococo bookcases from 1764, the second part summarises previously unused information on the library rules created by the Franciscan provincial Bernard Sannig in 1685, and the third part reports on the rediscovered copy of a Czech printed book from the 16th century, which was, together with other books, donated to the Franciscans of Prague by Jan Sferýn of Sferýn, a New Town burgher, and which was stolen from the library at Our Lady of the Snows in the first half of the 19th century.
\end{abstract}

Keywords: library of the Franciscan monastery of Our Lady of the Snows in Prague - furnishings - library rules - early printed books - Eligius Jakub Čečerle Bernard Sannig - Jan Sferýn of Sferýn

\section{Eligius Jakub Čečerle (1732-1816)}

Jméno truhláře a řezbáře, který v roce 1764 zhotovil pro pražskou františkánskou knihovnu regály z dubového dřeva, bylo se značnou mírou rezervy vysloveno ve studii publikované již před lety. ${ }^{1}$ Na tomto místě lze pro připomenutí rozvést základní východiska. Stěžejní údaj pro atribuci představuje prakticky soudobé sdělení, že jde o práci jednoho z řeholníků pražského konventu, ${ }^{2}$ jmenovitě neuvedeného: „Die Schränke und übrige Arbeit dieser Bibliothek, sind im Jahr 1764. von einem Bruder dieses Convent nett und äuserst sauber von eichenem Holz gemacht worden, bey welcher Gelegenheit man zugleich ein neues Bücher Reglement festsezte"3, čili, jak hovoří jeden z pozdějších autorů: ,,Je to vynikající řezbářská práce z roku 1764, provedená jedním z členů konventu, jehož jméno dnes již neznáme. " Regály postavené kolem všech čtyř stěn jsou stř́idavě konvexní a konkávní, takže jejich půdorys tvoří vlnovku, a zároveň kopírují i klenbu stropu.
Řezbářsky jsou vyzdobeny v rokokovém stylu s rokajovými ornamenty a jsou opatřeny nástavci ve tvaru kartuší, do nichž lze umístit papírové cedule s písmeny označujícími tematické okruhy signaturových řad. Otázkou však zůstává, proč je při počtu 24 písmenných signatur $(\mathrm{A}-\mathrm{Z})$ těchto nástavců pouze $11 .{ }^{5}$ Nové uspořádání knihovny, o němž se v souvislosti s pořizením nových regálů zmiňuje výše citovaný Hirsching a které zůstalo, přes několik drobných změn, de facto funkční dodnes, ${ }^{6}$ je dílem Prokopa Primera († 1796), ${ }^{7}$ tehdejšího knihovníka. Tento řeholník, podle Hirschinga ein sehr rechtschaffener Mann, ${ }^{8}$ rovněž pořídil v roce 1769 nový, v pořadí již třetí katalog, i když v něm jako autor není explicitně uveden. ${ }^{9}$ Podle zprávy z pamětních knih pražského konventu došlo roku 1780 k výměně oken v knihovně, přičemž skla zdarma poskytl sklenářský mistr Kreidl, řemeslníku, který je zasadil, konvent vyplatil 50 zlatých a truhlářské práce provedl již několik let předtím františkán jménem Eligius výslovně uvedený jako truhlár̆: ,,Eodem [Anno 1780] impositae sunt ad

${ }^{1}$ KAŠPAR 2005, s. 225-268, s. 234, zde zejména pozn. č. 63.

HIRSCHING 1788, s. 365-366. Podle něho všichni pozdější pisatelé, srov. ŠŤASTNÝ 1931, s. 85; VOLF 1933-1934, s. 158; BALCAR 1962, s. 89; srov. též zkrácenou verzi BALCAR 1985, s. 44; CHLÍBEC 1990, s. 195.

HIRSCHING 1788, s. 365-366.

${ }^{4}$ BALCAR 1962, s. 89 a BALCAR 1985, s. 44.

Jejich rámcový popis viz BALCAR 1962, s. 89, BALCAR 1985, s. 44 a KAŠPAR 2005, s. 256, ve všech př́padech však s chybným údajem, že jde o regály barokní. Celkový pohled do interiéru knihovny i na detaily řezbářské výzdoby regálů viz v obrazové př́loze k posledně citované studii.

${ }^{6}$ K tomu HIRSCHING 1788, s. 366, dále srov. ŠŤASTNÝ 1931, s. 85 a CHLÍBEC 1990, s. 199. K samotnému uspořádání podrobněji KAŠPAR 2005 , s. $246-247$.

Zemřel 30. 8. 1796 v Praze. Kněz, lektor filozofie, superior rezidence ve Skalce u Mníšku pod Brdy, zpovědník sester, jubilant slibů. Viz provinční nekrologium (soubor výpisů z nekrologií jednotlivých konventů převedený do elektronické podoby), k dispozici na františkánském provincialátu a též v knihovně u Panny Marie Sněžné. Srov. též KAŠPAR 2005, s. 234 a 235, pozn. č. 66.

8 HIRSCHING 1788, s. 366.

9 Národní archiv, fond Řád františkánů (dále NA, ŘF), inv. č. 561, kn. 168. Cathalogus Librorum Bibliothecae Conventus Neo-Pragensis Sanctae Mariae ad Nives Ordinis Fratrum Minorum Sancti Francisci Reformatorum, 1769. Nyní je coby dlouhodobá zápůjčka spolu se všemi ostatními staršími katalogy uchováván př́ímo v pražské františkánské knihovně. Ke katalogu srov. též KAŠPAR 2005, s. 246. 
Bibliothecam novae fenestrae, labor arcularius per nostrum fratrem Eligium, arcularium, ante plures annos factus fuit, vitra donavit Praenobilis Dominus Kreidl, Officinae Vitrariae Praefectus, Faber accepit 50 florenos. " ${ }^{10}$ Jak zde bylo řečeno na začátku, již byla vyslovena př́mo se nabízející domněnka, že tento řeholník by mohl být totožný s oním nejmenovaným, který roku 1764 zhotovil knihovní regály, a to tím spíše, že osm k jihu obrácených oken (dvě na severní straně jsou zazděná) je ozdobeno vyřezávanými třásněmi, které tvoří jakési záclony, jejichž styl i provedení jeví značnou podobnost s řezbářskou výzdobou regálů, což ostatně platí i pro dřevěné zárubně oken a dveří do knihovny. Ztotožnění bylo o to snazší, že v nekrologiu české provincie by z pouhých tř́ řeholníků prripadal v úvahu jediný (ostatní dva zemřeli v letech 1725 a 1761), a sice bratr laik a jubilant slibů Eligius Čečerle, ${ }^{11}$ který zemřel 9. června 1816 ve Voticích. Míru pravděpodobnosti této atribuce zásadním způsobem zvyšuje další pramen, jímž jsou značně torzovitá personalia františkánského konventu Nejsvětější Trojice ve Slaném. Ze seznamu řeholníků obývajících klášter vyhotoveného pro úřední potřebu dne 16. řijna 1786 vyplývá, že Eligius Čečerle, křestním jménem Jakub, narozený v roce 1732 v Kvíci (dřive Velká Kvíc u Slaného, dnes část města), zahájil dobu svého noviciátu u františkánů ve Slaném 10. srpna 1761 a ve stejný den o rok později složil řeholní sliby. Dále se zde uvádí, že hovoří česky a velmi málo německy a že v konventu působí jako truhlár. ${ }^{12}$ Není těžké si představit, že pokud byl zručným řemeslníkem, mohl být coby 32letý muž v plné síle krátce po svém vstupu do řádu dle zásady „,nové koště dobře mete“ povolán do Prahy a pověřen prací na mobiliáŕi tamní knihovny. Ten byl v každém př́ípadě zhotoven rukama skutečného mistra, a nyní lze tedy domněnku, že jím mohl být právě Eligius Jakub Čečerle, brát vážněji v potaz.

\section{Leges Bibliothecae Bernarda Sanniga (1637-1704)}

Nařízení z 15. ledna 1685 a na ně navazující knihovní řád pražské františkánské knihovny (Leges Bibliothecae) z téhož roku ${ }^{13}$ vydané tehdejším františkánským provinciálem Bernardem Sannigem ${ }^{14}$ zmiňuje zde již častěji citovaná studie, ${ }^{15}$ ovšem v době jejího vzniku byly oba zmíněné dokumenty v péči restaurátora Jiřího Vnoučka, a tudíž badatelsky nedostupné. Zvláštní pozornost jim proto věnoval později publikovaný samostatný článek, ${ }^{16}$ jehož součást představuje rovněž edice obou pramenů, ${ }^{17} \mathrm{v}$ níž byl značně porušený text originálu pražského knihovního řádu emendován podle analogického řádu určeného pro konvent $v$ Hostinném. ${ }^{18}$ $\mathrm{V}$ textu bylo také na základě informací z literatury uvedeno, že Leges Bibliothecae identického znění se dále dochovaly také v Moravské Třebové a v Plzni a že doklad o jejich existenci pochází též z Kadaně. Pozornosti autora článku i jeho recenzentů pohř́íchu unikla zásadní starší studie $\mathrm{k}$ danému tématu již před lety publikovaná $\mathrm{v}$ periodickém sborníku Strahovská knihovna. ${ }^{19}$ Nyní je možno využít př́iležitosti k částečné nápravě tohoto politováníhodného opomenutí alespoň prostřednictvím upozornění na tento důležitý text. V první části, pocházející z pera Marie Hálové, jsou přehledně a hutně shrnuty dějiny františkánské knihovny v Plzni včetně podrobnějšího rozboru několika celků různých dřívějších majitelů, kteří své knihy klášteru darovali či odkázali. ${ }^{20}$ Část druhá, od Josefa Hejnice a Václava Plachty, pak přináší popis exempláře Sannigova knihovního řádu dochovaného v plzeňské knihovně, ${ }^{21}$ který je kladen do souvislosti s rádem premonstrátského opata Jeronýma Jana Filipa Hirnheima (1637-1679)22 určeného pro strahovskou knihovnu, který v roce 1672 sepsal Bohumír Šimon Hohenberger $(\dagger 1680),{ }^{23}$ tehdejší bibliotekáă. ${ }^{24}$ Připojena je

${ }^{10}$ NA, ŘF, inv. č. 418, kn. 26. Archivum Conventus Neopragensis Beatissimae Virginis Mariae ad Nives I. (I-X) [1678-1851], fol. III 9v a NA, ̌̌F, inv. č. 420, kn. 28, Archivum Conventus Neopragensis Beatissimae Virginis Mariae ad Nives I. (I-X) [1678-1948], fol. III 9v. Srov. též KAŠPAR 2005, s. 234.

${ }^{11}$ Zde ovšem kvůli chybnému přepisu uváděn jako „Czoegerle“. Srov. též KAŠPAR 2005, s. 234, pozn. č. 63.

${ }^{12}$ NA, ŘF, inv. č. 2817, kart. 149. Konvent Nejsvětějšś Trojice ve Slaném. Personální záležitosti, seznamy osob, volby kvardiánů, korespondence, 1697-1944. Pro zajímavost lze zmínit, že rodina prakticky téhož jména (Čečrdle) žije dodnes ve Slaném, např. Jan Čečrdle (* 1981) v současné době (od roku 2010) působí jako ředitel tamního Vlastivědného muzea.

${ }^{13}$ Knihovna konventu františkánů u Panny Marie Sněžné (dále KKF u PMS) - historické fondy, obojí bez sign.

${ }^{14} \mathrm{~K}$ Sannigovi, který představoval jednu z nejvýznamnějších osobností v dějinách české františkánské provincie, přehledně KAŠPAR 2005, s. 229232, zde viz zejména základní biografické údaje a přehled pramenů a literatury na s. 229 v pozn. č. 25. O Sannigovi a jeho aktivitách srov. též článek citovaný zde níže v pozn. č. 16, tam pak viz s. 196-198, zejm. s. 196, pozn. č. 5.

${ }^{15}$ KAŠPAR 2005, s. 231-232.

${ }^{16}$ KAŠPAR 2013.

${ }^{17}$ Tamtéž, s. 204-205, příloha 1. a s. 206-207, př́loha 2. Na s. 208-209 v př́loze 3. je dále pro srovnání připojena edice knihovního řádu (Directorium pro Bibliothecariis), který je součástí katalogu františkánské knihovny v Kadani a sestavil jej roku 1778 tamní knihovník Eleuter Ritter († 1784), viz KKF u PMS - historické fondy, bez sign. Inventarium Bibliothecae Conventus Caadanensis, 1778, fol. 2v.

${ }^{18} \mathrm{NA}, \check{\mathrm{R} F}-$ Hostinné, kart. 3., sl. 2.

${ }^{19}$ HÁLOVÁ - HEJNIC - PLACHTA 1981-1982.

${ }^{20}$ Tamtéž, s. 101-109.

${ }^{21}$ Tamtéž, s. 109-110.

${ }^{22}$ Narozen 17. 5. 1637 v Opavě, zemřel 27. 8. 1679 v Praze. Do premonstrátského řádu vstoupil 1658 v Praze na Strahově, věčné sliby složil 27.4. 1659 tamtéž, kněžské svěcení přijal 7. 6. 1664 v Praze, teolog a filozof, v letech 1668-1670 vyučoval filozofii na řádové koleji Norbertinu a v arcibiskupském seminári, v letech 1670-1679 byl 53. strahovským opatem, zvolen byl 14. 1. 1670. DLABAČ, 1817, s. 41; GOOVAERTS 1899-1909, I, s. 389-390, III., s. 99-100; HURTER, 1903-1913, IV, sl. 315; OSN 1897, s. 313-314; TUMPACH - PODLAHA, 1930, s. 953-954. Srov. záznam v databázi Historického ústavu AV ČR „Řeholníci“ Dostupné z: http://reholnici.hiu.cas.cz/katalog/l.dll?hal 1000099821 [cit. 17. 9. 2021].

${ }^{23}$ Zemřel 10. 9. 1680 v Milevsku. Věčné sliby složil 2. 2. 1644 v Praze na Strahově, v letech 1672-1673 působil jako strahovský knihovník, byl rovněž hospodářským správcem a farářem v Popovicích u Teplé, nakonec žil v milevském klášteře. DLABAČ 1817, s. 42; GOOVAERTS 1899-1909, I, s. 392; v databázi „,̌̌eholníci“ je uvedeno datum úmrtí 4. 9. 1680. Dostupné z: http://reholnici.hiu.cas.cz/katalog/l.dll?hal 1000124746 [cit. 15. 9. 2021].

${ }^{24}$ Srov. PRAŽÁKOVÁ 1970-1971. Edici tohoto dokumentu s paralelním překladem do češtiny viz tamtéž, s. 406-412. Dále viz KNEIDL1971. Jde o faksimile s edicí a paralelním českým překladem (obojí s. 11-15) a s připojeným překladem do němčiny (s. 23-25). 
také edice plzeňského Sannigova řádu, ${ }^{25}$ jehož text je konfrontován s dalšími prameny, v první řadě s pražským exemplářem knihovního řádu, dále s výše zmiňovaným nařízením Bernarda Sanniga z 15. ledna 1685, se statuty české františkánské provincie z roku 1673 a konečně s Hirnheimovým knihovním řádem strahovským, přičemž autoři zdůrazňují, že na základě plzeňského řádu lze restituovat porušený text pražského exempláře, a vyslovují tezi, že oba řády měly společnou starší, dnes nezvěstnou předlohu. ${ }^{26} \mathrm{~K}$ edici je připojen doslovný český překlad textu Sannigova knihovního řádu z Plzně ${ }^{27}$ a v obrazové prríloze je celý článek doplněn fotografiemi plzeňského i pražského exempláře Sannigových Leges Bibliothecae. Takto lze tedy přehledně shrnout informace $\mathrm{k}$ druhdy opominuté stati a čtenářskému publiku ponechat $\mathrm{k}$ posouzení, do jaké míry se $\mathrm{v}$ tomto případě naplnilo ono klasické rčení „duo cum faciunt idem...“.

\section{Nově objevená kniha z pozůstalosti Jana Sferýna ze Sferýnu (ca 1548 - ca 1629)}

Osoba novoměstského radního Jana Chrysostoma Sferýna ze Sferýnu byla předmětem pozornosti jak obsáhlejší studie, ${ }^{28}$ tak kratšího doplňujícího konferenčního příspěvku, ${ }^{29}$ přičemž oba texty se krom Sferýnova životopisu zabývaly též jeho knižními dary pro bibliotéku františkánského kláštera u Panny Marie Sněžné. Zprvu se podařilo identifikovat 8 svazků inkunábulí a 2 konvoluty starých tisků ze 16 . století (celkem 9 prvotisků a 4 staré tisky), z nichž většinu Jan Sferýn františkánům věnoval v letech 1613-1618, přičemž dva prvotisky a jeden konvolut starých tisků se do jejich knihovny dostaly až po Sferýnově smrti v roce 1629 . Dva z těchto zmíněných 10 svazků (jedna inkunábule a jeden z konvoluti̊) mají Sferýnovu vlastnickou vazbu s heraldickým a iniciálovým supralibros a s vročením 1613, resp. 1612. ${ }^{30}$ Takovou vazbou je pak opatřen i další následně dohledaný prvotisk dochovaný ve fondu knihovny františkánského kláštera v Turnově, sanktorální část homiletické sbírky Sermones thesauri novi de sanctis francouzského dominikána Petra de Palude (Pierre de la Palu, ca 1277/1280 1342), vytištěné v Basileji u Bertholda Ruppela roku 1485. ${ }^{31}$ Sferýn ji roku 1613 prokazatelně věnoval zároveň spolu se svazkem obsahujícím temporální část Paludeho díla (Sermones thesauri novi de tempore) ve stejném vydání. ${ }^{32}$ Vlastnická vazba obou tisků je identická, s vročením 1613, oba též obsahují shodné Sferýnovo rukopisné ex libris a františkánský darovací př́ípis datované stejným rokem. ${ }^{33}$ Proč byla tato dvojice knih nelogicky rozdělena tak, že temporale zůstalo v pražské knihovně a sanctorale přišlo do Turnova, zůstává otázkou, a to tím spíš, že v Praze poté nezbyl žádný exemplář sanktorální části Paludeho sbírky, zato temporale rovnou v trojím různém vydání. ${ }^{34}$ Kniha se do Turnova dostala ještě v historické době, nebot' $v$ nejstarším katalogu pražské knihovny, pocházejícím zhruba z poloviny 17 . století, není uvedena, ${ }^{35}$ stejně jako v žádném z pozdějších seznamů. ${ }^{36} \mathrm{~V}$ Národní knihovně ČR je uchováván také středověký rukopis z přelomu 14. a 15. století, kdysi patřící Sferýnovi, a to liturgická příručka Rationale divinorum officiorum od francouzského kanonisty a biskupa v Mende Viléma Duranda (cca 1230-1296). Jak se tento rukopis v Národní knihovně ocitl, není známo. ${ }^{37} \mathrm{~V}$ jejích fondech, alespoň dle sdělení Jaroslavy Kašparové, by se však dnes mělo nacházet i několik dalších starých tisků

${ }^{25}$ HÁLOVÁ - HEJNIC - PLACHTA 1981-1982, s. 111-113.

${ }^{26}$ Viz tamtéž, s. 110 a s. 116 , pozn. č. 22.

${ }^{27}$ Tamtéž, s. 113-114.

${ }^{28}$ KAŠPAR 2008

${ }^{29}$ KAŠPAR 2009

${ }^{30} \mathrm{KKF}$ u PMS - historické fondy, sign. Františkáni Praha B c 6, C g 9 + C g 9 adl., C g 12, H f 11, H g 10, K f 3, P i 1, T f 6 (inkunábule) a sign. Františkáni Praha G b 3 + G b 3 adl., N c 19 + N c 19 adl. (tisky 16. století). Jejich soupis viz KAŠPAR 2008, s. 363-372, č. 1.-10., srov. také tamtéž, s. 356-361 a obr. č. 6.-10. Dva svazky prvotisků (sign. C g 12 a H f 11) jsou dnes bohužel deperditní, avšak jejich záznamy včetně provenienčních znaků se podařilo sestavit na základě starších bibliografií.

${ }^{31}$ KKF u PMS - historické fondy, sign. Františkáni Turnov B12a. Knihu eviduje též starý katalog knihovny konventu v Turnově, viz KKF u PMS historické fondy, bez sign. Catalogus librorum Bibliothecae Conventus Ordinis Fratrum Minorum Sancti Patris Francisci Turnovii, 1919 , pag. 8. Podrobný popis exempláře viz KAŠPAR 2009, s. 45-46 a pozn. č. 11.

${ }^{32}$ KKF u PMS - historické fondy, sign. Františkáni Praha H g 10. Podrobný popis viz KAŠPAR 2008, s. 369-370, č. 7 a obr. č. 7 , srov. také tamtéž, s. $357-358,359$.

33 Ohledně podrobnějších popisů srov. zde předchozí dvě pozn. č. 31 a 32.

${ }^{34} \mathrm{KKF}$ u PMS - historické fondy, sign. Františkáni Praha H g 10 a H f 11, oba prvotisky darované Sferýnem (viz zde výše pozn. č. 30 a 32), první, jak již bylo řečeno, vytištěný v Basileji u Bertholda Ruppela roku 1485, druhý vydal ve Štrasburku Martin Flach v roce 1493. Třetí inkunábule (sign Františkáni Praha H f 2) je z roku 1487 rovněž z Flachovy dílny, k této dále viz COPINGER 1895-1902, part 1., nr. 5.414 a k exempláři BALCAR 1960, č. 94. Františkánské rukopisné ex libris v této knize je nedatované, krom množství latinských a českých rukopisných marginálií obsahuje starší provenienci „WS“, resp. „Reverend[issimi]. d[omi]ni Wolff Sprudlik [?] [15]89“. Novější převazba svazku s využitím původních dřevěných desek pochází zhruba z 18. století a dle vzhledu vznikla již ve františkánském klášteře.

${ }^{35}$ Je zapsán v pamětní knize pražského konventu zahrnující léta 1611-1745, viz NA, ŘF, inv. č. 415, kn. 23. Archivum Conventus Neo-Pragensis Sanctae Mariae ad Nives, 1611-1745, pag. 707-762. Zahrnuje však pouze signaturové řady A-I, není tedy zdaleka úplný. V př́islušné signaturové řadě G (srov. pag. 743-749) není kniha uvedena. O katalogu podrobněji KAŠPAR 2005, s. 241.

${ }^{36}$ Viz KKF u PMS - historické fondy, bez sign. Catalogus Librorum Bibliothecae Conventus Neo-Pragensis ad Beatissimae Virginis Mariae ad Nives Ordinis Fratrum Minorum Sancti Patris Francisci Reformatorum, 1716, fol. [46]rv. Tamtéž jsou ovšem zapsány všechny tři výše uváděné prvotisky temporálních částí Paludeho díla, ovšem pod staršími signaturami G Sermonistae in folio ordinario 7 (dnes H g 10), 10 (H f 2) a 22 (H f 11). O katalogu podrobněji KAŠPAR 2005, s. 243. Dále viz NA, ŘF, inv. č. 561, kn. 168 (nyní KKF u PMS - historické fondy jako dlouhodobá zápůjčka). Cathalogus, 1769, pag. 105-106 a KKF u PMS - historické fondy, obojí bez sign. Cathalogus Librorum Bibliothecae Pragensis In Conventu Fratrum Minorum Sancti Francisci Reformatorum Sanctae Mariae ad Nives, 1815, pag. 81; Catalogus librorum bibliothecae Conventus Pragensis Sanctae Mariae ad Nives Ordinis Fratrum Minorum Sancti Francisci Reformatorum, [1851 post], pag. 135-136. Ke katalogům z let 1815 a 1851 post srov. KAŠPAR 2005, s. 247. V těchto třech citovaných katalozích jsou výše zmiňované prvotisky evidovány již pod stávajícími signaturami $\mathrm{H}$ f 2 , H f 11 a H g 10.

${ }^{37}$ Národní knihovna ČR, sign. XII A 2. Srov. TRUHLÁŘ 1905-1906, pars II., codex 2.079. Popis rukopisu KAŠPAR 2009, s. 46-47 a pozn. č. 13. 
z pozůstalosti Jana Sferýna, avšak konkrétní exempláře se zatím nepodařilo dohledat. Pro úplnost je třeba dodat, že nakonec byl také český rukopis Actio Calvinistica cum Catholicis Neopragensibus Anno 1620. Kalvinistské akcí s katolickými novoměstskými, jak se s nimi zacházelo v radě Nového Města pražského skrze nejedno obsílání, co k nim od purkmistra a jiných spoluradnich mluveno, co od nich žádáno, a co proti tomu od katolických za odpovéd' dáváno bylo, vše pořad krátce, však sumovně poznamenáno a v spis uvedeno - líčící události druhé poloviny roku 1620, kdy byli novoměstští katoličtí měšt'ané ve dnech 28. a 31. srpna, 3. a 23. září a 2. října celkem pětkrát předvoláni před nekatolickou městskou radu a zde vystavováni nátlaku, aby složili přísahu podle sněmovního usnesení, dekretu krále Bedřicha Falckého (1596-1632) a takzvané Konfederace českých stavů, přičemž katolíci přísahat odmítali, celou záležitost se jim dařilo protahovat různými odklady a nakonec ji za ně vyřešil výsledek bělohorské bitvy - určen jako dílo Jana Sferýna. ${ }^{38}$ V době zcela nedávné (záŕí 2021) se objevil další exempláŕ tisku patřící druhdy Sferýnovi a opatřený jeho vlastnickou vazbou se supralibros. Nachází se ve sbírkách Muzea Beskyd ve Frýdku-Místku ${ }^{39}$ a zprávu o něm podala tamní kurátorka Kateřina Janásová, jíž na tomto místě děkuji za kolegiálně poskytnuté informace a podrobnou dokumentaci. Jde o zatím první zjištěný jazykově český tisk pocházející ze Sferýnovy knižní sbírky, dílo italského jezuity Lucy Pinelliho (1542-1607) v českém překladu plzeňského faráře Petra Lintea Litoměřického z Pilsenburku († 1613) O dokonalosti zákonni knihy čtvery vytištěné v Praze u Kašpara Kargesia roku 1607. ${ }^{40}$ Kniha má identickou Sferýnovu vlastnickou vazbu s heraldickým a iniciálovým supralibros i se stejným vročením 1612 na přední desce, jako má jeden z konvolutů tisků 16. století, který Jan Sferýn v roce 1613 věnoval pražským františkánům, ${ }^{41}$ tedy dřevěné desky s pokryvem ze světlé vepřovice zdobené renesančním slepotiskem s rámovou kompozicí a s florálními (akantovými) a figurálními motivy (hlavy imperátorů), a s mosaznými háčkovými tordovanými sponami. Na titulním listu je
Sferýnovo rukopisné ex libris perem v češtině , Z kněh Jana Sferýna z Sferýnu“ a zbytky františkánského provenienčního přípisu, který je prakticky nečitelný kvůli razuře a částečnému porušení papíru. Bezpečně rozeznat lze pouze letopočet ,, 1629“, což by znamenalo, že tisk se do knihovny dostal až po smrti Jana Sferýna stejně jako několik dalších knih, které mají v provenienčních prrípisech stejné vročení a údaj, že se tak stalo v době působení Didaka Freye. ${ }^{42}$ Didak Frey († 1640), podle nekrologia i řádového historika Severina Vrbčanského († 1755) slavný kazatel, ${ }^{43}$ mohl snad být roku 1629 kvardiánem v Praze, avšak Vrbčanský v seznamu pražských představených pražského konventu jeho jméno neuvádí. ${ }^{44}$ Dále jsou na titulním listu ještě perem psané staré signatury , $J 111$ “ (přeškrtána) a „,D - 93“ (korigována na , $\left.D-187^{\prime 2}\right)$, které nijak nesouvisejí s františkánským prostředím, a také dvě razítka, „Archiv der Stadt Friedberg “ čili „Archiv města Místku“, což by krom doslovného významu mohlo také značit městské muzeum v Místku založené roku 1925, a „Mistní národní výbor v Místku-Lašské muzeum ve Frýdku “, které pochází pravděpodobně z let 19491964 a vztahuje se k dnešnímu Muzeu Beskyd. Vzhled svazku zcela odpovídá již výše uvedené úpravě knih provedené po roce 1764, respektive v letech 1764-1769, knihovníkem Prokopem Primerem. Hřbet šitý na tři vazy je přetřený šedou fermeží, v prvním mezivazném poli byl nepochybně černou barvou psaný zkrácený název knihy, dnes ovšem přelepený papírovým štítkem s pozdější signaturou ,,D-187“, ve druhém mezivazném poli se nachází dobře čitelné impressum „Pragae 1607“. Přes druhé a třetí mezivazné pole je ještě dostatečně patrné černou barvou psané první písmeno signatury, ,, $P^{\prime \prime}$, a ve čtvrtém poli, nad spodním kapitálkem, pak zbytky arabské číslice „,98“. Malé písmeno udávající formát a druhdy psané červenou barvou vedle litery „ $P$ “ již nelze rozeznat, nicméně v úvahu připadají, vzhledem $\mathrm{k}$ tomu, že jde o běžnou osmerku, nejpravděpodobněji písmena ,, $c$ “ či „, $b$ “. Nejstarší, avšak neúplný katalog pražské knihovny $\mathrm{z}$ poloviny 17 . století signaturovou řadu $\mathrm{P}$ vůbec neobsahuje. ${ }^{45}$ Starý katalog knihovny $\mathrm{z}$ roku 1716 eviduje tři

${ }^{38}$ NK ČR, sign. XV E 5 /4., ff. 1r-8v. Srov. TRUHLÁř, 1905-1906, pars II., codex 2.722. Popis rukopisu včetně atribuce viz KAŠPAR 2009, s. 41-43 a pozn. č. 13 a jeho edici tamtéž, s. 52-61, též obr. č. 2. Srov. též KAŠPAR 2008, s. 351-354 a obr. č. 4.

${ }^{39}$ Muzeum Beskyd ve Frýdku-Místku, staré tisky, inv. č. FM 27767 S. K tomuto exempláři viz PUMPRLA 1985, s. 111, č. 385, tento záznam však neobsahuje údaje o vazbě a provenienci. Srov. také KNIHOPIS, Dodatky, č. 7.178.

${ }^{40}$ Bibliografické informace viz DE BACKER Al. - DE BACKER, Aug. - SOMMERVOGEL - CARAYON - BLIARD - RIVIÈRE 1890-1932, VI., sl. 810, č. 10; JUNGMANN 1825, č. V. 1.507; JUNGMANN 1849, č. IV, 1881; JIREČEK 1875-1876, I, s. 453; KNIHOPIS, Dodatky, č. 7.178. V italském originále vyšlo poprvé jako Gersone della perfezione religiosa. Napoli: Giovanni Giacomo Carlino, 1601, srov. DE BACKER Al. - DE BACKER, Aug. - SOMMERVOGEL - CARAYON - BLIARD - RIVIĖRE 1890-1932, VI, sl. 811, č. 10. U překladu z italštiny do latiny, z něhož vycházel Petr Litoměřický, připadají v úvahu tři edice, a sice De perfectione religiosa libri quatuor. Colonia Agrippina: Balthasar Clypeus, 1602 (DE BACKER Al. - DE BACKER, Aug. - SOMMERVOGEL - CARAYON - BLIARD - RIVIÈRE 1890-1932, VI., sl. 811, č. 10; VD17 uvádí dvě variantní vydání, viz VD17 12:104110P a VD17 1:075320F), dále Colonia Agrippina: Joannes Mertzenich, 1603 (Tamtéž; VD17 12:104155C) a Moguntia, Balthasar Lippius 1604 (Tamtéž; Das Verzeichnis der im deutschen Sprachraum erschienen Drucke des 17. Jahrhunderts \{Dostupné z: http://www.vd17.de/ [cit. 13. 9. 2021]\} opět uvádí dvě variantní vydání VD17 23:320076M a VD17 3:671263V). Exemplář latinského vydání z roku 1602 (VD17 12:104110P) viz též v KKF u PMS - historické fondy, sign. Františkáni Praha P a 255 (srov. též KKF u PMS - historické fondy, bez sign. Catalogus, 1716, fol. [94]r pod sign. P in duodecimo 134; dále NA, ŘF, inv. č. 561, kn. 168 \{nyní KKF u PMS - historické fondy jako zápůjčka\}. Cathalogus, 1769, pag. 211; KKF u PMS - historické fondy, obojí bez sign. Cathalogus, 1815, pag. 145; Catalogus, [1851 post], pag. 238).

${ }^{41}$ KKF u PMS - historické fondy, sign. Františkáni Praha G b 3. Jeho popis viz KAŠPAR 2008, s. 370-371, č. 9 a obr. č. 6, srov. též s. 357-358, 360, 361.

${ }^{42}$ KKF u PMS - historické fondy, sign. Františkáni Praha N c 19 a dnes deperditní Františkáni Praha C g 12 a H f 11. Popisy viz KAŠPAR 2008, s. 371-372, č. 10 a obr. č. 8 , srov. též s. 356-357, s. 364, č. 2 a s. 370 , č. 8 , k oběma srov. též s. 356.

${ }^{43}$ Narozen v Praze, zemřel 21. 2. 1640 tamtéž. Kněz, slavný kazatel. Provinčni nekrologium. Viz též VRBČANSKÝ 1746, s. 36: „,P[ater]. Didacus Frey Pragensis ... a Praedicatione Verbi Dei famosus “. Srov. též KAŠPAR 2008, s. 356, pozn. č. 95.

${ }^{44}$ VRBČANSKÝ 1746, s. 108. Srov. též KAŠPAR 2008, s. 356, pozn. č. 95.

${ }^{45} \mathrm{NA}, \breve{\mathrm{R} F}$, inv. č. 415, kn. 23. Archivum, 1611-1745, pag. 707-762. 
exempláře zmiňovaného českého překladu, a to pod staršími signaturami P in octavo majori 35 (35. De Perfectione religiosa Libri $4^{\text {tuor }}$. Authore R[everendo]. P[atre]. Luca Pinello, bohem[ice]., Pragae 1607) a P in octavo majori 36 (36. iidem secundo, ibidem, eodem a 36. [!] iidem secundo, ibidem, eodem) ${ }^{46}$ Všechny exempláře tehdy byly pohromadě a druhý a třetí z nich byly dosti neobvykle označeny stejným pořadovým číslem. Která z těchto starých signatur by mohla odpovídat knize po Sferýnovi, nelze s určitostí říci, avšak vzhledem k rané době jejího nabytí lze hypoteticky uvažovat o té první, tedy P in octavo majori 35. Již zmiňovaný i nejednou citovaný katalog Prokopa Primera z roku 1769 svědčí o změně v uspořádání knihovny, jež nastala po roce 1764 a která se týkala i těchto tř́ tisků. První exemplář je zapsán pod signaturou P b 79 (79. R[everendi]. P[atris]. Lucae Pinelli, S[ocietatis]. J[esu]. de perfectione Religiosa Libri IV., bohem[ice]., Pragae 1607) ${ }^{47}$ a další dva pak jako P c 98 (98. $R$ [everendi]. P[atris]. Lucae Pinelli, S[ocietatis]. J[esu]. de perfectione Religiosa Libri IV., bohem[ice]., Pragae 1607) a P c 99 (99. Ejusd[em]. iidem Libri IV., $2^{\text {do }}$, bohem[ice]., ibid [em]., eod[em].). ${ }^{48}$ Stejně tak je eviduje i katalog $\mathrm{z}$ roku 1815, P b 79 (79. $R$ [everendi]. P[atris]. Lucae Pinelli $S$ [ocietatis]. J[esu]. de perfectione Religiosa Libri IV bohem[ice]., Pragae 1607), ${ }^{49}$ P c 98 (98. R[everendi]. P[atris]. Lucae Pinelli S[ocietatis]. J[esu]. de perfectione Religiosa Libri IV bohem[ice]., Pragae 1607) a P c 99 (iidem Libri IV bohem [ice]. $2^{\text {do }}$, ibidem, eod [em].). ${ }^{50} \mathrm{~V}$ katalogu, který pořídil Čeněk Lichtblau (1813-1887) ${ }^{51}$ v 50. letech 19. století, je ovšem zapsán pouze exempláŕ pod signaturou P b 79 (79. O dokonalosti zákon[n]í od Luk[áše]. Pinella (vzácná), Praha 1607). ${ }^{52}$ Zápis je učiněn již v češtině, na rozdíl od předchozí praxe, kdy byly všechny knihy zapisovány latinsky, poněvadž Lichtblau psal údaje o knihách důsledně vždy v př́slušném jazyce a užíval i dvojího písma (kurent pro němčinu, humanistickou polokursivu pro ostatní jazyky včetně češtiny). Na signaturách P c 98 a P c 99 však již figurují jiné knihy. ${ }^{53} \mathrm{Z}$ výše uvedeného jasně vyplývá, že kniha po Janu Sferýnovi se signaturou P c 98 a druhý exemplár stejného díla pod signaturou P c 99 byly v době mezi lety 1815 a 1851 z pražské františkánské knihovny blíže neznámým způsobem zcizeny, přičemž druhý z uvedených svazků je v tuto chvíli ztracen nadobro a ten první, druhdy Sferýnův, se nezjištěnou cestou dostal do sbírek Muzea Beskyd. ${ }^{54}$ Třetí exempláŕ, který v knihovně zbyl, má černou barvou psaný původní zkrácený latinský název a impressum přelepené papírovým štítkem s titulem v češtině a rokem vydání „,O dokonalosti zákonni 1607. “, což je obvyklá úprava knihovníka Čeňka Lichtblaua, který nejen do katalogu, ale i na svazcích samotných užíval namísto do té doby důsledně psaných latinských pojmenování naopak názvů v prŕslušných vernakulárních jazycích, v praxi se jednalo především o němčinu a o češtinu, vedle latiny řeči v knihovně nejčastěji zastoupené. Byl to dozajista výraz jeho vlasteneckého a národoveckého smýšlení, jelikož podle svědectví zhruba o půlstoletí pozdějšího ,, lidu byl uprrimným rádcem a přitelem, a jako horlivý vlastenec budil lásku mezi lidem k českým knihám, jež pưjčoval ze své bohaté knihovny ". ${ }^{55}$ Řečený exemplár je také evidován $\mathrm{v}$ př́slušných bibliografických soupisech. ${ }^{56}$ Kniha nově identifikovaná v Muzeu Beskyd rozhodně představuje cennou součást sferýnovského celku a v souvislosti s ní se na jazyk i do pera prrímo dere otřepaná sentence o tom, že ,habent sua fata libelli““.

\section{Prameny:}

Knihovna konventu františkánů u Panny Marie Sněžné Národní archiv, fond Řád františkánů

\section{Literatura:}

BALCAR 1960: BALCAR, Dalibor. Soupis prvotiski̊ františkánské knihovny v Praze. Praha: Státní knihovna ČSR, 1960.

BALCAR 1962: BALCAR, Dalibor. Vznik, vývoj a možnosti současného využití fondů klášterních knihoven spravovaných státni knihovnou ČSSR v Praze (se zvláštním žretelem $k$ prvotiski̊m). Diplomová práce na katedře knihovnictví Institutu osvěty a novinářství Univerzity Karlovy v Praze, vedoucí Jaroslav Drtina, Praha 1962.

BALCAR 1985: BALCAR, Dalibor. Z historie pražských klášterních knihoven spravovaných Státní knihovnou ČSR v Praze. Miscellanea Oddělení rukopisů a starých tiskủ Státni knihovny ČSR 1985, roč. 2, s. 29-51, s. 44.

COPINGER 1895-1902: COPINGER, Walter Arthur. Supplement to Hain's Repertorium Bibliographicum or collections towards a new edition of that work, part 1.-2. London: Henry Sotheran, 1895-1902.

DE BACKER Al. - DE BACKER, Aug. SOMMERVOGEL - CARAYON - BLIARD - RIVIÈRE 1890-1932: DE BACKER, Aloys - DE BACKER,

\footnotetext{
${ }^{46} \mathrm{KKF}$ u PMS - historické fondy, bez sign. Catalogus, 1716, fol. [88]v.

${ }^{47} \mathrm{NA}, \breve{R} F$, inv. č. 561, kn. 168 (nyní KKF u PMS - historické fondy). Cathalogus, 1769, pag. 220.

48 Tamtéž, pag. 226.

${ }^{49} \mathrm{KKF}$ u PMS - historické fondy, bez sign. Cathalogus, 1815, pag. 150.

50 Tamtéž, pag. 154.

${ }^{51} \mathrm{~K}$ této pozoruhodné postavě podrobněji KAŠPAR 2005, s. 235. Vedle pramenů a literatury zde citovaných viz též WILHELM - MINAŘÍK 1909-1910, s. 128. O Lichtblauově katalogu srov. též KAŠPAR 2005, s. 247. Jeho autorství není v daném knižním soupise explicitně uvedeno, avšak informuje o něm starší literatura.

${ }^{52} \mathrm{KKF}$ u PMS - historické fondy, bez sign. Catalogus, [1851 post], pag. 245.

${ }^{53}$ Viz tamtéž, pag. 250. Františkáni Praha P c 98 je MURATORI 1780 (Bibliografie cizojazyčných bohemikálních tisků do roku 1800 \{Dostupné z: http://clavius.lib.cas.cz/katalog/[cit. 13.9. 2021]\} BCBT05799; Das Verzeichnis Deutscher Drucke des 18. Jahrhunderts \{Dostupné z: http://www. vd18.de/ [cit. 13. 9. 2021]\} toto vydání neuvádí) a P c 99 česká verze téhož MURATORI 1778 (Knihopis 5.974, exemplář evidován v Dodatcích).

${ }^{54}$ Podle sdělení K. Janásové nelze z dochované dokumentace zjistit, jak a kdy jej muzeum získalo.

${ }^{55}$ WILHELM - MINAŘÍK 1909-1910, s. 128.

${ }^{56}$ ŠŤASTNÝ 1931, s. 224; Knihopis, č. 7.178.
} 
Augustin - SOMMERVOGEL Carlos - CARAYON, Auguste - BLIARD, Pierre - RIVIĖRE, Ernest Marie. Bibliothèque de la Compagnie de Jésus. Bruxelles - Paris Toulouse, 1890-1932.

DLABAČ 1817: DLABAČ, Bohumír Jan. Chronologicum Necrologium Abbatum et Canonicorum Praemonstratensium Sioneorum... . Praha: Josefa Sommerová, 1817.

GOOVAERTS 1899-1909: GOOVAERTS, Léon. Écrivains, artistes et savants de l'Ordre de Prémontré, 1.-4. Bruxelles: Oscar Schepens, 1899-1909.

HÁLOVÁ-HEJNIC-PLACHTA 1981-1982: HÁLOVÁ, Marie - HEJNIC, Josef - PLACHTA, Václav. Z dějin plzeňské františkánské knihovny. Strahovská knihovna 16-17, 1981-1982, s. 101-117.

HIRSCHING 1788: HIRSCHING, Friedrich Karl Gottlob. Versuch einer Beschreibung sehenswürdiger Bibliotheken Teutschlands nach alphabetischer Ordnung der Oerter 3./I. Erlangen: Johann Jakob Palm, 1788.

HURTER 1903-1913: HURTER, Hugo. Nomenclator literarius catholicae theologiae, 1.-5. Oenipontum: Libraria Academica Wagneriana, 1903-1913.

CHLÍBEC 1990: CHLÍBEC, Bohdan. O současném stavu knihovny konventu františkánů u Panny Marie Sněžné v Praze. Miscellanea ORST NK ČR 1990, roč. 7., č. 1, s. $193-202$

JIREČEK 1875-1876: JIREČEK, Josef. Rukovět’ $k$ dějinám literatury české do konce XVIII. věku ve spůsobě slovníka životopisného a knihoslovného, 1.-2. Praha: Bedřich Tempský ml., 1875-1876.

JUNGMANN 1825: JUNGMANN, Josef. Historie literatury české aneb Soustavný přehled spisů českých s krátkou historií národu, osvícení a jazyka. [1. vydání.] Praha: Antonín Straširypka, 1825.

JUNGMANN 1849: JUNGMANN, Josef. Historie literatury české... [2. vydání.] Praha: František Řivnáč, 1849.

KAŠPAR 2005: KAŠPAR, Jan. Knihovna kláštera františkánů u Panny Marie Sněžné v Praze (dějiny, knižní fond a současný stav). In: Historia Franciscana II. Kostelní Vydři: Karmelitánské nakladatelství, 2005.

KAŠPAR 2008: KAŠPAR, Jan. Novoměstský radní Jan Sferýn ze Sferýnu a část jeho knižní sbírky v knihovně kláštera františkánů u Panny Marie Sněžné. In: Documenta Pragensia 27, 2008, s. 337-381.

KAŠPAR 2009: KAS̆PAR, Jan. „Actio Calvinistica cum Catholicis Neopragensibus Anno 1620،“ Rukopisné svědectví pražského měšt’ana Jana Sferýna ze Sferýnu. $K$ výzkumu zámeckých, měštanských a cirkevních knihoven. „Jazyk a řeč knihy". Opera romanica 11, 2009, s. 41-66.

KAŠPAR 2013: KAS̆PAR, Jan. Leges Bibliothecae z roku 1685 Bernarda Sanniga (1637-1704) v knihovně kláštera františkánů u Panny Marie Sněžné v Praze. In: CÍSAŘOVÁ SMÍTKOVÁ, Alena - JELÍNKOVÁ, Andrea - SVOBODOVÁ, Milada (edd.). Libri magistri muti sunt. Pocta Jaroslavě Kašparové. Praha: Knihovna Akademie věd ČR, 2013, s. 195-213.
KNEIDL 1971: KNEIDL, Pravoslav. Řád Strahovské knihovny 1672. Leges Bibliothecae Strahoviensis... Praha: Památník národního písemnictví - Pragopress, 1971.

KNIHOPIS: TOBOLKA, Zdeněk - HORÁK, František URBÁNKOVÁ, Emma - WIŽĎÁLKOVÁ, Bedřiška JARÝ, Vladimír - ANDRLE, Jan. Knihopis československých tisků od doby nejstarši až do konce 18. století, I./1., II./1.-9. Praha: Státní tiskárna - Nakladatelství ČSAV, 1925-1967 + Dodatky, I./1., II./1.-9. Praha: Národní knihovna ČR, 1994-2010.

MURATORI 1778: MURATORI, Lodovico Antonio. O pravé křest'anské pobožnosti. Praha: Normální tiskárna, 1778.

MURATORI 1780: MURATORI, Lodovico Antonio. Die wahre Andacht des Christen. Wien - Prag - Triest: Johann Thomas von Trattner, 1780.

OSN: Ottův slovník naučný: ilustrovaná encyklopaedie obecných vědomostí. Díl XI. Praha: Jan Otto, 1897.

PRAŽÁKOVÁ 1970-1971: PRAŽÁKOVÁ, Běla. Strahovský knihovní řád z roku 1672. Strahovská knihovna 5-6, 1970-1971, s. 405-420, s. 412-414.

PUMPRLA 1985: PUMPRLA, Václav. Soupis starých tiski̊ ve sbírce Okresního vlastivédného muzea ve Frýdku-Místku. Frýdek-Místek: Okresní vlastivědné muzeum, 1985.

ŠŤASTNÝ 1931: ŠŤASTNÝ, Jaroslav. Staré české knihy konventu F. M. F. u P. Marie Sněžné v Praze. Vlast 47, 1931, s. 84-87, 129-132, 170-175, 220-225, 266-270.

TRUHLÁŘ 1905-1906: TRUHLÁŘ, Josef. Catalogus codicum manu scriptorum latinorum qui in $C$. R. Bibliotheca publica atque universitatis Pragensis asservantur. Pars I.II. (Codices 1 - 2.830). Praga: Regia Societas Scientiarum Bohemica, 1905-1906.

TUMPACH - PODLAHA 1930: TUMPACH, Josef PODLAHA, Antonín. Český slovník bohovědný 4. Praha: Cyrilometodějská tiskárna a knihkupectví Václav Kotrba, 1930.

VOLF 1933-1934: VOLF, Josef. Prohlídka knihovny kláštera františkánů u Panny Marie Sněžné v Praze. Vitrinka 10, 1933-34, s. 158.

VRBČANSKÝ 1746: VRBČANSKÝ, Severin. Nucleus Minoriticus... Praha: Jan Karel Hraba, 1746.

WILHELM - MINAŘÍK 1909-1910: WILHELM, Bonaventura - MINAŘÍK, Klemens. Dějiny klášterů františkánských $v$ Čechách a na Moravě. Otisk z časopisu „Serafinské květy“. Třebíč: Českomoravská františkánská provincie, 1909-1910.

\section{| Jan Kašpar}

Památník národního písemnictví

Obora Hvězda

Praha 6 - Liboc 